\title{
The Bank of Naples and the struggle for regional power in Risorgimento Italy
}

\author{
Maria Stella Chiaruttini* \\ Department of Economic and Social History, University of Vienna, Austria
}

(Received 14 May 2020; final version accepted 24 January 2021)

\begin{abstract}
Drawing on the history of the Bank of Naples, this article sheds new light on the power struggle between the central government and the Southern elites in Risorgimento Italy. Since unification, the Bank has been portrayed as the archetypal victim of a predatory (Northern) Italian government. This article, by deconstructing the myth surrounding the Bank, shows how this characterisation was carefully crafted by its Neapolitan management. Exploiting to the fullest the new political and economic role they had acquired under the aegis of a constitutional government, the Bank's governors appropriated and invested with new meanings Risorgimento ideals to further the Bank's cause as well as their own. Constantly shifting the focus from finance to politics, they posed as champions of those municipal, regional or even national liberties the government was either unable or unwilling to defend. This narrative provided an ideological smokescreen obscuring the economic and partly private nature of the confrontation between the central government and the Bank, and reinforced the view of a South victimised by the new Italian state still in currency today.
\end{abstract}

Keywords: Southern Question (Questione meridionale); banking; financial elites; Bourbons; cultural history; discourse analysis.

\section{Requiem for a bank}

For many in Naples, 26 November 2018 was a day of regional mourning. On that day, the Bank of Naples (Banco di Napoli) finally disappeared from the Italian financial landscape, absorbed into Intesa Sanpaolo, one of the largest European banking groups. To quote from an online newspaper, it was the end of 'an ancient, intense history made of great feats and financial achievements' weaving together 'the city and "its" Bank ... over more than five centuries', a history marking 'all the most important events first in Naples and later in all Southern Italy under the Kingdom of the Two Sicilies'. A 'love story' ending in 'resignation' for 'all those Neapolitans' seeing in the merger with Intesa Sanpaolo (heir to some major Northern Italian banks) the transformation of their Bank and its branches into powerless 'outposts of the empire' within a Northern colonialist framework (Mataluni 2018).

Banks are rarely the subject of emotional obituaries, nor is their fate usually invoked to promote historical revisionism. In this article I aim to explain why the Bank of Naples is an exception to the rule and how this answer can shed new light on the nineteenth-century history of Southern Italy and the way in which it is recounted. The Bank of Naples is indeed an intriguing subject for historians. Its success over the centuries clearly belies the stereotype of an unenterprising South trapped in secular underdevelopment (see Pescosolido 2017, 123-41). At the same time the Bank - the

\footnotetext{
*Email: maria.chiaruttini@univie.ac.at
}

(C) The Author(s), 2021. Published by Cambridge University Press on behalf of the Association for the Study of Modern Italy. This is an Open Access article, distributed under the terms of the Creative Commons Attribution-NonCommercial-NoDerivatives licence (http:// creativecommons.org/licenses/by-nc-nd/4.0/), which permits non-commercial re-use, distribution, and reproduction in any medium, provided the original work is unaltered and is properly cited. The written permission of Cambridge University Press must be obtained for commercial re-use or in order to create a derivative work. 
largest Southern credit institution at the time of unification - has also come to embody the 'lost cause' of the South against the national state and the Northern interests it allegedly represents. According to the current neo-Bourbon narrative, the Bank represented the South's best hopes of economic prosperity, hopes which were largely frustrated in unified Italy by ruthless Northern politicians and bankers, who used all means possible to weaken it to the advantage of the future Bank of Italy, thus contributing to the emergence of the North-South divide (Zitara 2011). ${ }^{1}$

This view is a popularised version of a thesis developed by Capecelatro and Carlo (1975), who drew their inspiration from a selective reading of the Bank's official histories, which present it as both a regional champion and the victim of a hostile government, although in a more guarded fashion (Demarco 1958, 1963; De Rosa 1961). These official histories, in turn, rely to a large extent on sources that - this article contends - reflect the Bank's constructed identity more than its underlying reality, an identity which eventually became dominant in the South thanks to the concerted efforts of its management and the growing ascendancy at a local and national level of the Historic Left (made possible by massive Southern support).

Such one-sided interpretations opposing Northern and Southern economic interests can be easily challenged from the point of view of financial history (Chiaruttini 2020a, 2020b). In this article, however, I will focus less on their intrinsic merit than on their genesis in the aftermath of national unification. By deconstructing the 'mythical biography' of the Bank of Naples created by its management in the 1860 s, this study aims to contribute to the century-old debate on the 'Southern Question' (Questione meridionale) from a novel perspective encompassing financial and cultural history, two fields that have remained mutually exclusive in Italian historiography. In doing so, it brings to the fore the role of Southern financial elites in shaping power relations in post-unification Italy while creating an enduring myth.

Indeed, it is worth emphasising the marginalisation of these elites in the literature on the Southern Question. It is well known that in Liberal Italy the Bank of Naples became a valuable pawn in the power game between the Historic Left and Right due to its public nature, its statutory relationship with the Municipality of Naples and its vast resources. Yet, even in the works devoted to Southern politics in general (Capone 1970) and the 'Neapolitan Question' (Questione di Napoli) in particular (Aliberti et al. 1971; Musella 2010), the Bank neither takes centre stage nor are its internal dynamics interrogated. Recently, the persistent power wielded by Southern financial elites in post-unification Italy has been documented quantitatively by Schisani, Balletta and Ragozini (2021) but overall the literature on the Southern Question, still flourishing today, remains focused on social, political, real-economy or purely cultural factors - a perspective from which financial institutions and agents are mostly expunged (see e.g. Petrusewicz 1998; Dickie 1999; Moe 2002; Daniele and Malanima 2011; Barbagallo 2013; Felice 2013; Pescosolido 2017). ${ }^{2}$ This historiographical gap is then easily filled by the romanticised story of the Bank of Naples circulated by neo-Bourbon apologists.

Analysing the discourse surrounding the Bank of Naples in Liberal Italy, its manufacturing and motivations, is only one of the many possible ways to bridge this gap. Focusing exclusively on the Bank of Naples is also a very partial exercise that ignores at least two other powerful interest groups, namely the Bank of Sicily (Banco di Sicilia) (Asso 2017) and the Southern financiers siding against the Bank of Naples. Nevertheless, despite its narrow focus, this approach integrates the existing literature in several respects. It confirms, from an unusual vantage point, the insights of social and political studies on the fragmented identity of the South and its elites and the highly deceptive nature of their conflict with central authority (e.g. Pezzino 1992; Riall 1998, 2013). In underlining that the convergence of Southern economic interests around the Bank of Naples was partly a figment of the Bank's public-opinion crusade and should therefore not be taken at face value, this analysis put yet another nail in the coffin of a monolithic conceptualisation of 
the South as a coherent macro-region, which, albeit thoroughly refuted by scholars, is still prevalent in the public debate (Donzelli 1990; Dickie 1999, 10-14; Corona 2019). Furthermore, it contributes to the literature exploring how the Southern Question - or, as in this case, a piece of it - was ideologically and linguistically constructed (Petrusewicz 1998; Dickie 1999; Moe 2002; De Francesco 2012). To borrow from Petrusewicz (1998, 13-14), my analysis, by 'questioning the authorship' of the narrative concerning the Bank of Naples, at the same time 'reconsider[s] ... the cultural autonomy' and the resourcefulness of the Southern financial elites, 'challenging ... [their] subaltern role' in negotiating power, fabricating a Bourbon black legend and even reframing the Risorgimento discourse.

The history of the Bank demonstrates how the Italian government - often blamed for its indiscriminate policy of centralisation ${ }^{3}$ - early on devolved economic power to the Neapolitan elites, who, mastering the art of dissent within a constitutional state, used that power effectively to bolster their position at local and national levels. In so doing, they opportunistically combined myths and metaphors from the armouries of Risorgimento ideals and Bourbon propaganda. Contingent economic interests were constantly shrouded in patriotism. The Bank projected a heroic image of itself by stressing its antiquity, philanthropic character, allegiance to the South and persecution by the central government, whether Italian or Bourbon. All these features were, however, highly problematic in light of Risorgimento values. Antiquity evoked the past glories of the resurrected nation but also an embarrassing connection to Bourbon rule. It also contrasted with the youthful ambitions of the new state, bearing the standard of progress and civilisation. Therefore, the Bank, while priding itself upon its venerable antiquity, had at the same time to prove able to regenerate itself - just like the redeemed nation - so as to fulfil its providential role in the South and all Italy.

There were other paradoxes. The Bank of Naples' philanthropic character - inherited from the old charities who had laid the foundations of Neapolitan public banking - smacked of pauperism in a conservative but anticlerical state and initially provided a pretext for its opponents to demand its downgrading to a deposit institution. Playing the card of philanthropy was also difficult given the instances of mismanagement and scandals brought to light by insiders amidst internecine strife. The nineteenth-century lexical ambiguity of the word Neapolitans - meaning both citizens of Naples and all Southerners living on the mainland - served the Bank's interest remarkably well, for it allowed a fundamentally municipal institution to pose as a city and a regional champion at the same time. This identity had however to be accompanied by stalwart patriotism to avoid the damning charge of particularism - a mortal sin in a country unified after long centuries of factionalism. By playing freely with history and backdating the Bank's persecution by the state to Bourbon times, its advocates forged a weapon with which to politically blackmail the Italian government, in danger of following in the footsteps of the hated Bourbons. But if challenging the central government head-on was appealing to Bourbon nostalgics and leftists opposing the Right's centralist policies, it risked blemishing the Bank's patriotic image. In order to reassert that patriotism, the Bank skilfully appropriated the Risorgimento myth of unity, freedom and material progress by refashioning itself as the guardian of constitutional order against a government that was itself only too ready to encroach on the private sphere.

This public image was constructed in a variety of ways, through pamphlets, press campaigns, parliamentary speeches and official documents. Most of them were, however, produced or inspired by just a few authoritative and talented board members of the Bank, in particular Michele Avitabile and Nicola Nisco. The former, Director General from 1860 to 1864, entered the Bank administration under the Bourbons and became a local celebrity for championing the Bank's cause against the government, which eventually dismissed him. Although compromised by his association with the Bourbon regime (L'Italia 1865), he managed to capitalise on his dismissal and enter the 
Chamber of Deputies as a member of the opposition, strenuously denouncing the Right's banking policy. The latter, a Bank official from 1863 to 1867, was, by contrast, a well-known nationalist, Bourbon exile and protean right-wing deputy. He was also a gifted student of economics (Aliberti 1969, 59-105; Schisani 2013). However, a closer examination of his writings and activity both against and in favour of the Bank of Naples reveals a more enigmatic figure, often willing to either defend or attack the Bank depending on his changing private interests, while shaping his public persona as a Bourbon martyr and Risorgimento hero. The Bank's apologists did not share a political creed, yet they often made common cause against the government to promote not so much the South's interests as the Bank's and their own. Over time, therefore, due to its inherent opposition to the Right's banking policies, the discourse on the Bank of Naples resonated more easily with the Left's rhetoric denouncing the Right's debasement of Risorgimento ideals in the name of a money oligarchy and a Leviathan state.

\section{Banking history in a nutshell}

To illustrate these points, this essay concentrates on the main conflicts between the Bank and the governments led by the Historic Right from Italian unification until the Left's electoral victory in the mid-1870s. Following Cavour's masterplan, the Right repeatedly tried to impose the Piedmontese National Bank (Banca Nazionale) - the predecessor of the Bank of Italy - as the country's only bank of issue. The National Bank, a private joint-stock company founded in 1849 with Cavour's help, enjoyed the government's favour for many reasons. Politically, it was aligned with the ruling party, it was mainly owned by Northern capitalists, and it was always willing to finance nationalist wars. Economically, it was a modern, efficient machine managing a nationwide credit and payment system through its branches. That system could, if need be, easily print banknotes to support a government chronically short of money. Immediately after unification, the National Bank spread its branches across the entire country and was entrusted with the recoinage of the old Italian currencies, an operation which filled its coffers with coin. In May 1866 its banknotes were declared inconvertible legal tender amidst a major financial crisis. This privilege ended only in 1874, and before then turned the National Bank into a market hegemon, earning it the enmity of the other few regional banks of issue (the largest of which was the Bank of Naples) and of all those who, on various grounds, feared a banking monopoly. Nevertheless, the Right's attempts to grant the National Bank further privileges such as the management of the provincial state treasuries and their large capital inflows floundered, while the 1874 banking reform strengthened the surviving banks of issue. ${ }^{4}$

The Bank of Naples - as the Bank of the Two Sicilies (Banco delle Due Sicilie) was renamed in 1861 - was very different from the National Bank. In Naples, several deposit banks had been operating since the sixteenth century. Originally started as offshoots of charities founded by lay confraternities, they soon developed into fully-fledged banks issuing transferable deposit notes. After the outbreak of the French Revolution, their assets were seized by the Bourbons and sacrificed on the altar of throne and religion. Under French rule, the ancient banks were repeatedly reformed and eventually merged into a governmental bank, whose coffers were duly emptied. After the Bourbons came back into power, they confirmed the public character of the new bank (under the direct control of the finance minister) together with the name chosen by Murat - Bank of the Two Sicilies - and its formal division into two departments, one mostly serving the Treasury and the other private clients. The Bank was made the state treasurer and its Regent was put in charge of the Mint. Meanwhile, its notes rapidly spread across the whole country thanks to the numerous legal privileges they enjoyed. Although never grossly misused by the government, 
the Bank was primarily used to finance the public household and its lending to the private sector (including pawnbroking loans) was severely constrained by the near absence of a branch network (Chiaruttini 2020a, 2020b).

Before unification, the Bank of Naples was akin to a huge public money box mainly active in Naples, employing hundreds of employees to handle its byzantine routines and complex accounting. After unification the Bank's existence was a mixed blessing for an Italian government committed to private - instead of public - banking. Southern ministers such as Filippo Cordova, Antonio Scialoja and Giovanni Manna repeatedly tried to scale back its operations. In 1863 Manna even proposed to put a halt to its discounting activities. The uproar in Naples was so great that he soon had to relinquish his plans. Instead, the government renounced its control over the Bank and entrusted its administration to a Board of Directors and a General Council formed by representatives of the Municipality, Province, Chamber of Lawyers, Tribunal and Chamber of Commerce of Naples and, to a lesser extent, Bari, together with the Director General and two Inspectors selected by the government from a short list drafted by the General Council. Unsurprisingly, those public bodies greeted the reform as enlightened and forced the government to backtrack when it later tried to increase the powers of its own appointees. The Bank's representatives systematically opposed the granting of any privilege to the National Bank, while trying to negotiate extremely profitable deals such as a multi-million recoinage contract and the management of the Southern treasuries. These were all attempts, as we shall see, invariably portrayed as patriotic deeds. Moreover, their very failure was taken as a sign of the government's abhorrence of anything Southern - notwithstanding the many branches the National Bank was establishing in the South, which were lending hundreds of millions of lire under Southern management and with the full support of some of the major Neapolitan bankers (Chiaruttini 2020a, 2020b).

\section{An old bank for a young nation}

Antiquity is part and parcel of a sort of 'mythical biography' of the Bank of Naples that has been consciously developed and advertised since the early nineteenth century, haunting both popular and scholarly historians to this day. Since Bourbon times this notion has been drummed into public consciousness to the extent that reminding the audience of the Bank's ancientness was and still is the standard way of introducing any discourse about it - be it a decree, an inquiry, or a piece of research. While today the Bank's antiquity provides historians with a good argument to justify their interest (Demarco 1996, vol. 5: 9-108, vol. 6: 1-19; Costabile and Neal 2018), in the past it was a useful marketing device to instil trust - the most precious asset in banking - into the public. Moreover, it endowed the Bank with an aura of sacrosanctity and immortality which made any attacks against it look little short of sacrilege.

In 1816, the Bourbons referred to the ancient city banks in the very decree establishing a new governmental bank in their stead, in order to emphasise the legitimacy of their restoration and generate a narrative of discontinuity and counter-revolution. The decree's preamble presented the creation of the Bank of the Two Sicilies as the coronation of their efforts to 'give a definitive organisation to the Banks of this Capital' and contrasted it to the 'many and most grievous novelties' introduced during the French 'military occupation' concerning 'this ancient and most useful national institution [i.e. the banks]' ${ }^{5}$ In fact, although in business practices and daily routine the new bank closely resembled the old Neapolitan banks, its nature and aims were profoundly different. The old banks had been originally erected by public piety as private, charitable institutions. The Bank of the Two Sicilies was, by contrast, a creature of the government born out of the 
ashes of the ancient banks the government itself had burnt to the ground. Its main end was to regulate the monetary and credit market, while at the same time supporting public finances. Moreover, legitimist and Napoleonic government attempts at reform evidenced a much stronger continuity than that between the new bank and its forefathers, as the Bank's very name and its division into two departments plainly attested. Revealingly enough, the decree's preamble referred to the old banks with apparent nonchalance as collectively representing one single institution - an inaccuracy which would later become commonplace in the discourse on the Bank of Naples. Even more mistakenly, it evoked a national identification for these banks. In fact, the only truly national institution was the new public bank, issuing notes which, thanks to legal privileges, soon spread across the whole South - certainly not the old banks, active in Naples alone.

Besides celebrating the Bourbon restoration, the blurring of lines between the old banks and the new Bank of the Two Sicilies was also essential for reassuring markets. After nationalising the old banks, the government was now appropriating their secular creditworthiness and disguising as much as possible its own new role as ultimate arbiter of the banking market. Although the Bank of the Two Sicilies was nothing other than a governmental department fully under the control of the finance minister, the government took care to present it as a sort of technical institution which set firm boundaries in its management between the interests of the Treasury and the general public. The newly acquired absolute power of the state over banking mimicked the fluid and pliable system of informal checks and balances characteristic of the ancien régime (see Valsecchi 1951). It had to appear restrained by laws and awed reverence towards the 'sanctity' of private deposits as well as towards ancient customs and institutions predating the monarchy itself. Reaping the fruits of a contradictory policy (privileging a public institution while soft-pedalling its governmental character), the Bourbons could attract huge private deposits - mostly used to finance the Treasury - despite the ever-looming danger of mismanagement, inflation or even outright appropriation, as happened in the late eighteenth century. As we shall see, this intentional ambiguity regarding the Bank's true nature - was it a government department or an inherently autonomous institution? - set the stage for an acrimonious dispute between the Italian government and the Bank soon after unification.

Antiquity, however, was a double-edged sword. This became immediately clear after the Bourbons' fall, when the Bank had to prove its right to survive in what Italian nationalists portrayed as a 'regenerated' country bearing the torch of progress. If the Bank was quick to brandish the sword of tradition in order to fend off any attempt at its life, ancientness - in the mouth of its adversaries - was a synonym for obsolescence. ${ }^{6}$ It was a concept which seemed the best argument for its abolishment, chiming with the much-trumpeted backwardness of the South as a whole (see e.g. Petrusewicz 1998). In the words of Nicola Nisco, the Bank of Naples in 1861 was 'a temple of Vesta', 'a monument of antiquity that should no longer last, at least for the sake of the government's decorum'. Nisco was at that time in charge of the Department of Agriculture, Industry and Commerce of the temporary government ruling the mainland South in 1860-1, a position he had earned by plotting for the Piedmontese against the Bourbons. In that capacity he was zealously working to promote credit development and most notably the establishment in the South of the Piedmontese National Bank, despite the initial opposition of the Neapolitan top merchants. ${ }^{7}$ However, once elected to parliament, in a fit of oblivion he accused 'those called upon to rule the new State' of considering the Bank of Naples to be 'a squalid, old monument whose existence ought no longer to be tolerated' (Nisco 1866, 17). At that time the Bank was older than it was in 1861 , when Nisco confidentially advocated its demise, but since 1863 he had been appointed to its board, so his oversight was understandable. 
Challenging the Bank's right to survival was soon portrayed by friendly press as but one facet of the philistine nature of the Italian government, utterly ignorant of and outrageously indifferent to Southern customs and traditions. And this despite the fact that it was a group of Southern ministers, well versed in financial matters, including Cordova, Scialoja and Manna, who struck, or tried to strike, some of the harshest blows to Southern public banking. In 1867, at the height of the fight between the National Bank and the Bank of Naples over the Treasury service, L'Avvenire (1867b), the latter's mouthpiece, warned that posterity would damn Italians, 'dominated by an unreasonable, and often unjust, hatred of the old', who 'unwisely demolished many excellent, nay even perfect, parts of [their own] administrative institutions' ${ }^{8}$ In a clear dig at the National Bank, the newspaper reversed the standard argument about obsolescence: 'valuable institutions' (read: the Bank of Naples) had been 'neglected' in order to replace them with 'false systems' (read: hegemony of the National Bank) which were 'in fact nothing other than the new edition of old and reprehensible errors'. While the latter appeared already 'old and unsuitable' to the times, the former, 'handed down by the wisdom of our forefathers', were so robust and wisely ordained as 'to defy the tooth of time'. Such blunders were due to the 'abnormal' application of the 'concept of unity' to the administrative domain. Radical reforms endangering Bourbon institutions and aiming at building a coherent national framework were decried as 'reckless craving for innovation'.

Unification, so much praised in the political domain, appeared dangerous when it impinged on economic interests and the regional balance of power. While paying lip service to political unification, as early as 1861 the Neapolitan newspaper Il Pungolo (1861b) also deplored that 'the concept of unification translate[d] into a rage for destruction' targeting the city Bank. ${ }^{9}$ In a high-wire attempt to ideologically disparage unification in banking at a time in which the Risorgimento had become a state religion, the paper established a politically hazardous parallel between the latter and the French Revolution, depicted in terms more familiar to the Jesuits and diehard conservatives than to Italian patriots. Just as the French Revolution had laid waste to the Genoese banking system in the name of reform, despoiling the old Banco di San Giorgio, the newspaper denounced, so too the Italian government was trying to destroy the Bank of Naples under the pretext of unification.

Two full columns of invective were needed to deny the urgency of establishing a branch of the National Bank in Naples, a measure which ought to rank far down on the list of government priorities after rearmament, administrative reform, railway and port investments. Like Nisco, however, Il Pungolo too suffered from providential amnesia: only seven months earlier it had rebuked the government for not having yet ensured the unreserved acceptance of the National Bank notes by the Bank of Naples. In January - but no longer in July - the mutual acceptance of notes between the two institutions was proclaimed 'one of the first measures to be taken after abolishing the political and financial barriers between upper and southern Italy'. Such reciprocity would even 'pave the way ... to the merger' of the two banks (Il Pungolo 1861a).

In 1864, another local newspaper, La Borsa, commemorated the failed attempt by Manna in 1863 to put an end to the Bank's discounting activities in inflammatory terms:

The vandalistic system of destroying anything existing in Naples did not stop ... in front of this institution, which the country [il paese, read: Naples] did not allow to be destroyed, and vigorous protest won out against the destructive rage, hence the Bank managed to survive in spite of the government, which had to curb its abuse of power and yield humiliated to the decrees of public opinion (La Borsa 1864, my emphasis).

The Bank's Director General Avitabile, who had orchestrated the press campaigns in defence of the Bank in those years, was by contrast celebrated as a formidable 'obstacle to governmental 
cupidities' and a champion against 'men who no longer [had] qualms about putting their hands on the most inviolable things' ${ }^{10}$

\section{Inventing a black legend}

According to L'Avvenire (1867b), the only extenuating circumstance for disrespecting the old administrative order was the 'painful memories bequeathed by the [Bourbon] past'. Crafting a Bourbon black legend for banking, too, was fundamental for the Bank's administration in order to ingratiate itself with the new government and, if need be, to defame it as the heir to Bourbon tyranny. ${ }^{11}$ If blaming the Bourbons for their conservatism and Neapolitano-centrism in banking is all too easy, the Bank of Naples was the only institution which, lavished with government favours, could not complain. Moreover, its management had been arguably complicit in the stifling of competing credit institutions and the endless delaying of banking expansion outside the capital's precincts (Chiaruttini 2020b). If on the eve of unification the Bank of Naples could boast the highest amount of deposits in all Italy, it was certainly not simply because it descended from Renaissance charities but because of the privileges it had been granted in 1816. Yet acknowledging this debt of gratitude to the former regime was not only politically unpalatable, it would also prevent the Bank of Naples from posturing as a perennial victim of central state despotism. ${ }^{12}$

In 1863 the government definitively discarded the idea of getting rid of the Bank of Naples to the advantage of the National Bank. By that time the Bank of Naples was no longer the undisputed master of the Southern monetary market and had to bow to the National Bank, rapidly expanding across the whole peninsula and (unsuccessfully) claiming monopoly rights under the auspices of the Right. The government, however, compensated the Neapolitan political and business elites by putting the management of the city Bank in their hands. This was no minor achievement, considering that Southerners were at the same time co-opted into the national and provincial boards of the National Bank. In April 1863 Minister Manna relinquished his former projects to reduce the Bank of Naples to a mere deposit and pawnbroking institution. He renounced direct government control over the Bank in favour of an administration representing all the main public bodies in Naples and Bari, by then the only branch of the Bank. In Naples, the 1863 reform was duly praised. Years later, the President of the Bank's General Council, Tito Cacace, still proclaimed that 'Manna's intelligent and patriotic' reform, by acknowledging the Bank's primitive independence from the government denied by the 'evil' Bourbons, had 'restored' the Bank according to the principles of economic 'progress' and 'civilisation' enshrined in 'free rule'. ${ }^{13}$

Cacace's eulogy - the Bank's supporters produced endless variations - combines patriotic thanksgiving with a confession of faith in progress (which could sometimes go hand in hand with praise of the Bank's ancientness) and in the civilising mission of the Italian state in politics as well as banking. This was topped with hypocrisy towards Manna - formerly pilloried as a public enemy scheming against the Bank - and conspicuous historical falsehoods. It is indeed difficult to see how the Italian government could restore a Bank which prior to the nineteenth century did not exist and was never independent from the government, nor how the Bourbons could be blamed for the favours bestowed on the very bank their successors were allegedly 'restoring'. According to a historically slightly more accurate Nisco, the Bank 're-established [by the Bourbons] behind a façade of autonomy always remained ... a fiscal department owing to the traditional disrespect for any law that characteristically informed that regime'. According to a 'shameless custom of the Bourbon administration', the Bank was regarded not as 'a person but a slave, whose patrimony belonged to the august lord by right of seigniorage' (Nisco 1866, 86, 93).

The former subordination of the Bank to the central government was typically termed an 'abnormal state' (e.g. Nisco 1866, 97), while the restoration of the Bank's 'natural autonomy' - 
that is, its control by local authorities - was portrayed as 'the most eloquent act of [the government's] loyalty and justice'. ${ }^{14}$ In 1864 , trying to reassure the 'very many' who feared that 'any [government] provision tended to the one and only aim' of 'destroying' the Bank, Rodolfo Englen, a member of the Bank's board of directors and brother of the left-wing politician Mariano, praised the Italian government for being 'inspired by sentiments of justice and liberty', unlike the Bourbon one, 'which did not identify its interests with those of the public' and was the sole arbiter in public and private matters. ${ }^{15}$ A century later, the Bank's historian Demarco (1958, 466) celebrated the 1863 reform in similar terms as the 'extermination' of the 'Bourbon octopus' .

While the Italian government could rejoice in the gratitude of Neapolitan notables, it soon discovered what a dangerous weapon fictional history could be. In 1863 the government had de facto graciously handed over Italy's largest deposit bank - a state-controlled institution - to the city public administrations. Neither was the Bank of Naples the reincarnation of the old Neapolitan banks nor were local public bodies direct descendants of the charities that had founded them. Yet the government was praised not for this concession but for 'releasing' a mythical Bank predating the Bourbons and kept 'hostage' by their despotic government and which, unfathomably, was said to retain a sort of 'private' character - before and after the 1863 reform - despite still being fully public. The government, however, recalled the Bank's actual origins and nature when it had to settle its debts with it and negotiate future taxes with its management.

As official correspondence made abundantly clear, the only mandate the government gave to the royal commissioners appointed to this task was to negotiate a good deal, seeking some extra money rather than the Bank's life. To bolster their bargaining position, the commissioners, led by a knowledgeable and well-respected Neapolitan bureaucrat, put forward the argument that the Italian government, as the Bank's legitimate heir, was entitled to compensation for its handover to the local administration in the form of the Bank's real estate and retained profits. Although the government could lay such claims with good reasons, they were only seen as instrumental to reaching a fair deal. In other words, it was a bluff, for the government had no intention to seriously undermine the Bank's position nor to take back the present, namely the Bank itself, which it had just given to the Neapolitan elites. This strategy, however, backfired. Repaying in kind, the Bank asked for compensation for the expropriation of the old banks before 1816. Moreover, as lamented by the commissioners themselves, the Bank immediately brought those negotiations to the public eye, unleashing a press campaign 'of every colour', with 'rags' as well as 'quality papers' naming and shaming royal commissioners and lambasting them as 'thieves, despoilers, harpies, villains'. ${ }^{16}$ A compromise acceptable to both parties was eventually reached but it cost the government its political reputation in the local arena.

Besides stirring up public opinion, the Bank's representatives manipulated history to face the government with an artificial, and highly political, trade-off: either favour the Bank and prove a just, constitutional government, or oppress the Bank as the Bourbons did. Drawing on the rhetoric of the Bourbon Restoration, which conceived the plural system of the ancient deposit banks as a single unit, the Bank's advocates, Nisco and Avitabile in particular, evoked the ghost of a private, pre-existing Neapolitan Bank which had been enslaved by the Bourbons, awaiting release by a democratic government which would give it back to its legitimate owners, the Neapolitan citizens. This metaphor was particularly appealing, as it equated the bondage of the Bank with that of the South as a whole. It demonstrated the impeccable nationalist credentials of the Bank's defenders, reaffirmed the common destiny of the Bank and the South, and put pressure on the government to distance itself from the former regime.

The Bourbon government, Nisco claimed, '[had] been not the founder but the destroyer of the Bank of Naples' 17 'Amidst some insolent remarks and more than a few irritating words' Avitabile, 
one commissioner reported, 'maintained that the Bank was ... exclusively private' and that the government 'intervened only to despoil' it. The royal commissioners were awash with antiquarian tirades on the banks' depredation by King Ferdinand during the Napoleonic Wars - 'most futile arguments', in their view, concerning a vaguely identified entity, ${ }^{18}$ which however established a direct link between the thievish aims of the past and the present government. The banks' nationalisation in the 1790s was dubbed a 'slaughter perpetrated by the Government's bad faith' and contrasted with the renaissance experienced by the Bank thanks to the 1863 reform and the 'independence' and 'freedom' Victor Emmanuel had brought to the nation. ${ }^{19}$ This was indeed a puzzling interpretation of history in light of the market hegemony enjoyed by the Bank under the Bourbons and its constant complaints against the privileges bestowed upon the National Bank after unification. However, it not only conformed to the myth of the 'resurrected nation' but also squared with the new power acquired by the local administration over the Bank.

According to Avitabile, the claims of the Italian government exceeded even those of the 'fiercest absolutism'. ${ }^{20}$ The current dispute with the government, Nisco conceded, would have been acceptable under the Bourbon tyranny. 'But nowadays, when the Government must live off justice to be supported by public opinion', it was no longer acceptable, or else the Italian government, the 'emanation of freedom and national will', risked being confused with the one 'which was by its nature the negation of God'. 'He who wants united Italy to be completed and last cannot permit the Government of Italy to be even suspected of aspiring to dispossessions and robberies', Nisco pontificated. 'It is to say the least strange and fantastic' - he continued - 'that ... the Italian Government, which desperately needs to be rich in order to be strong, wants to pillage our Banks'. The only way to achieve public prosperity was through credit: hence, by resisting the government's voracity, the Bank was acting 'in the best interest of the Government' itself. '[E]very member of [the General] Council' - we are informed - had 'the deep feeling of serving the true interests of the Government, or more precisely the true interests of Italy in promoting those of the Bank of Naples'. ${ }^{21}$

Laying any claim to the Bank's assets was not only unjust and contrary to national interests, the Bank's board maintained, but undermined the entire administrative system by implicitly granting the government the privilege of extortion. Accepting the claims of the royal commissioners, they insisted in truly apocalyptic terms,

would logically subvert the whole social structure, ... we should regard even ourselves as dead, now that we have passed from a regime of despotism to one of liberty. ... Thus liberty would be the cause and the legal motivation to seize other people's property. ${ }^{22}$

The Italian government had been so successful in emancipating the Bank and the elites sitting on its board that it was lectured, privately and publicly through the press, about its true interests and those of the nation. Liable to succumb to the 'vice of the Bourbons', it had to be watched over by the Bank, with its frank and loyal opposition, ${ }^{23}$ an institution too patriotic to have anything to do with grossly material interests.

\section{(Not) for one's own sake}

The Bank of Naples always took pride in its philanthropic origins, which had allegedly permanently endeared it to the Neapolitans. Yet its philanthropy could at best be detected in donations - which the 'greedy' National Bank also made - or in its pawnbroker activities, which were actually a source of revenue. Pawnbroking, moreover, was not only a source of frequent complaints concerning the quality of the service but also of occasional embezzlement, the scale of which, on one occasion at least, the Bank admitted was such as to 'turn anyone pale'. ${ }^{24}$ Throughout 
the 1860s and 1870s, mismanagement across all the Bank's departments was severe enough to attract the government's attention, though without serious consequences for its administrators (Chiaruttini 2019, 273-80). This was a thorny and recurring issue which the Bank's historian De Rosa (1961) glosses over, and which was partly - and perplexingly - exposed by Nisco himself.

Nisco did not only enjoy posing both as a paladin of the Bank and, as a man of the Right, a privileged interlocutor between it and the government. He also wished to earn fame as an enlightened reformer who had improved what he called the Bank's 'Adamitic' accounting system and succeeded in establishing its first branch outside the South, in Florence, a move whereby the Bank left, 'like the Neapolitan people, its old boundaries, and [took] on a new life together with the nation' (Nisco 1866, 122-3, 149). As Branch Director in Florence, his autocratic manners and boundless ambitions were quickly resented by his colleagues in Naples, who initially lauded him only to soon dismiss him on allegations of abuse of power and embezzlement - a charge which would not have surprised Cavour, who considered him a greedy and incompetent administrator. ${ }^{25}$ In retaliation, Nisco launched a press campaign against the Bank denouncing its questionable practices. In 1868 he even testified against the Bank before the Parliamentary Commission on Note Inconvertibility, although one member of the inquiry commission, Seismit-Doda, could not come to terms with Nisco's previous apologetic stance towards the Bank, held when he was still sitting on its board (Camera dei Deputati 1869, vol. 3: 206-7).

Neither ill fame, however, nor manifest self-interest could ever deter the Bank's management from flaunting its generosity, in contrast to the venal National Bank. When in 1864 Avitabile almost succeeded in negotiating with the government a deal over the withdrawal of the old Southern currency that would bring into the Bank's vault such an amount of money as to dwarf the cumulative reserves of all other Italian banks of issue, this proposal was advertised as being eminently patriotic rather than immensely profitable. ${ }^{26}$ By making a clean sweep of the millions of ducats still ubiquitous in the South, the Bank would serve the regional market and the state not only economically but also in a quintessentially political way. Ducats were a tangible proof of still unachieved unity and a constant reminder of the Bourbons, inflaming loyalist fantasies and making less costly the prospect of a Bourbon restoration (Chiaruttini 2018, 14). The Bank would thus put an end to 'a condition that ... revives in our enemies the hope of a return to the past, which, however foolish and impossible, nonetheless disturbs the harmony ... necessary to consolidate freedom'. ${ }^{27}$ Sadly for the Bank, despite its willingness to enrich itself in the name of the fatherland, the convention with the government was eventually rejected by the Court of Auditors, a decision which was entirely attributed to the interference of the National Bank. ${ }^{28}$

From the mid-1860s onwards, the Bank successfully engaged in a furious battle to prevent the National Bank from obtaining the management of the Treasury service in the South and the flows of taxpayer money connected to it. To secure them for itself instead, the Bank went so far as to consider officially bribing the government by devolving to it all the extra profits it made when increasing its discount rate above 6 per cent. It goes without saying that this would once more have shown its 'beneficent nature' and even helped to 'cement Political Unity'. ${ }^{29}$ When in 1866 a financial crisis led the government to declare the National Bank notes inconvertible legal tender - a deadly blow to all other banks of issue and as such publicly denounced - the Bank of Naples endeavoured to put some order into the erupting monetary chaos as a survival strategy to retain public favour in the face of the overwhelming power of its Northern rival. Yet, this too was duly publicised as another sign of its mighty heart. Extolling the virtues of the Bank, L'Avvenire (1866b) remarked that 'the Bank's behaviour has always been ... eminently patriotic', pursuing 'the public's interests rather than [its own] extraordinary advantage'. Albeit 'constantly 
under attack ... from powerful forces, ... undermined by the various finance ministers, whose favour it has never enjoyed, the Bank has always responded with forbearance, with generosity'.

By contrast, the 'intrinsic goodness' of the National Bank was only mentioned sarcastically (Il Pungolo 1866). The National Bank, a joint-stock company run in the interest of its (mainly Northern) shareholders, could not but be avaricious, unlike the Bank of Naples, which, 'belonging to no one and therefore to everybody', could afford the luxury of altruism, or so it was claimed. ${ }^{30} \mathrm{~A}$ rather strange claim indeed, since the Bank was fully controlled by a clique of Neapolitan notables who could exploit it as a mine of political and personal favours without even risking their own fortunes as common shareholders did.

\section{'Native' banking}

The Bank constantly emphasised, in highly emotional terms, its allegiance to Naples and its people. This rhetoric, however, was permeated by lexical ambiguity, whereby it was never crystal-clear if the 'country' or the 'nation' the Bank extended its benefits to was Italy, the South or just Naples. The Bank also liked to present Neapolitans as standing united on its side. As Englen put it, 'the Bank [is] an institution to which the eyes of all Neapolitans are turned ... as their shrine', a shrine for which they had always felt 'reverence and love'. ${ }^{31}$ This despite the fact that the city's largest merchant bankers had readily jumped on the National Bank's bandwagon as early as 1861 and Southern investors flocked to subscribe its capital increase in 1865 (Chiaruttini 2019, 221, 271).

To bolster its shaky claim to the unwavering devotion of Southerners, the Bank instrumentalised cultural prejudice, representing them as overly emotional, excitable, distrustful people bound to tradition, whose choices as bank clients appeared dictated by sensibility rather than sense. ${ }^{32}$ An anonymous newspaper reader, or more likely a straw man, defending the Bank of Naples against Nisco's allegations of mismanagement in an open letter, stated that 'Our Bank ... is for us Neapolitans an institution to which are ... linked not only our economic interests but also our dearest affections. It is for us, I daresay, what the holy ark was for the Hebrews' (L'Avvenire 1868b). The Bank's notes, we are elsewhere reminded, were trusted, nay venerated, so much so that Southerners would pay their taxes more readily, had provincial treasury services been provided by their Bank (L'Avvenire 1867a). The Bank of Naples, Englen remarked, was not only 'useful', but 'deemed necessary by us Neapolitans given our habits and sympathies, and given also its nationality [my emphasis]', a nationality which was clearly not the Italian but the old Neapolitan one. ${ }^{33}$ In a similar vein, L'Avvenire (1867c) argued that banking policy had to adapt itself to the 'temper and traditions of our keen and distrustful peoples', who, abandoning the cliché for once, were described as 'sharp and subtle in their reasoning'.

Nisco, attacking the government for its backing of the National Bank, warned it that credit 'is an emanation of our personality, ... our beliefs, our habits, our knowledge and even our prejudices' and that trying to sway those of Neapolitans in favour of a non-native institution was tantamount to 'compromising Italian unity'. Overly confident and soon belied by the facts, he proclaimed that, although '[m] any new orders and names [had] been imposed on the Southern people', no one could ever force them to accept the National Bank notes as readily as they did those of the Bank of Naples (Nisco 1863, 66). In fact Southerners, perfectly able to act in their own best interests, rapidly learned to appreciate the advantages of the former's notes, which, unlike the latter's, were accepted all across Italy and not in the South alone. ${ }^{34}$

Through parliamentary speeches and newspaper articles, the advocates of the Bank of Naples sought to engrave in public opinion the notion that any disregard for the Bank's interests - in whose enrichment lay all hopes for the South's regeneration (Nisco 1866, 91-2) - was a sign of 
the government's contempt for anything 'Neapolitan' (Nisco 1866, 17-18; L'Avvenire 1868a). Nisco $(1863,66)$ went so far as to openly blame the government for the failed establishment of a Neapolitan joint-stock bank of issue instead of the National Bank branch in 1861, a failure which previously, boasting privately with Cavour, he attributed to his own sabotage as a government bureaucrat (see above). Just as the French were blamed for their attempts to remould the old Neapolitan banks in too Gallic a fashion in the early nineteenth century (Nisco 1866, 61-2), so too was the Italian government criticised for trying to 'import' Piedmontese banking institutions in its 'mania for unifying' (Nisco 1863, 66).

However, posturing as the only 'native', and therefore 'legitimate', banking hegemon in the mainland South was obviously not enough to discredit the progressive penetration by the 'foreign' National Bank within the increasingly integrated economy of a country whose raison d'être was Italian nationalism. Hence, in a series of open letters, Nisco $(1866,15)$ denied that the Bank of Naples was 'a parochial institution' (monumento da campanile) around which clustered 'municipal aspirations and passions', evoking instead the great services it would render to the whole nation. Yet, in his private correspondence with future Treasury Minister Luzzatti, Englen deplored the potential growing influence of representatives from outside Naples within the Bank's board resulting from the progressive expansion of the Bank's network of branches. While a certain degree of representation was necessary in politics, applying the principle of representative government to banking could, in his view, only lead to chaos: ideally, no branch or head office other than Naples should dictate the Bank's policy. ${ }^{35}$

Thus, despite its careful obstruction of a greater representation of provincial interests within its overwhelmingly Neapolitan board, the Bank increasingly posed not only as a regional but as a national champion in order to compete ideologically with the National Bank. It refashioned itself as Italy's most powerful bulwark against the market tyranny of a would-be central bank. Politically, like a large part of the Southern elites, it allied itself with the Left, systematically thwarting the Right's increasingly feeble attempts to grant any sort of privileges to the National Bank alone and succeeding in imposing an oligopoly of banks of issue that survived, though far from unscathed, until Mussolini's times. Containing the market power of the National Bank was likened metaphorically to the struggle for freedom against (financial) landlordism and 'feudalism', a slogan strongly resonating in a region whose 'backwardness' was mostly attributed to feudal remnants and failed land reforms. Under the Bourbons, the Bank had been treated as a 'fief' of the Treasury. The Bank's self-assigned historical mission was now to prevent Italian markets from becoming a 'fief' of the National Bank, a form of financial subjugation that would betray the progressive ideals of the Risorgimento.

From the Bank's perspective, it was disheartening that Italy, the cradle of modern banking, had to witness 'centralism and banking monopoly defended from the seat of power at the time of [its] resurrection [risorgimento]' ${ }^{36}$ In parliament, Avitabile thundered that Italy ought not to become 'the land of plenty of the banking high aristocracy' - a paradoxical proclamation considering that the Bank of Naples belonged to that exclusive club of large banks with the right of note issue definitively institutionalised by the 1874 banking reform. What was at stake, according to this picture, was not just the freedom of the infant Italian markets but of the Italian government itself. Any further privilege would degrade the state to a 'fief' of the National Bank, which would then 'appoint deputies, senators, ministers and public officials'. 'Gentlemen,' Avitabile harangued his fellow MPs in 1870 amidst cheers from the left benches, 'let's build in Italy a Government free in its financial policy: financial monopoly kills political freedom. ${ }^{37}$

In its polemic, the Bank went so far as to contest the traditional role of the National Bank whose monies had financed all the nation's holy wars - as the Risorgimento standard-bearer. If 
the government, to use a popular expression, 'enfeoffed' (infeudare) the National Bank with Italian finances, it would then need the bank's blessing even to wage wars of national liberation, a blessing the National Bank would give only as long as this promised large enough dividends to its shareholders (L'Avvenire 1867b). Amidst the growing disillusion that characterised post-unification Italy, the Bank of Naples - entrusted to local administrations but nurturing its image as a private agent - stood up as a defender of national liberties, be it in the financial or political domain, against a government all too ready to betray them.

\section{Conclusion}

The Bank of Naples, the most iconic credit institution in Southern Italy since Bourbon times, has always been extolled for its unrivalled contribution to the Southern economy, a view deeply entrenched in Neapolitans' collective imagination. Typically, both in academic and popular literature, the Bank is taken as a symbol of the South's glorious past and its struggle to assert itself in unified Italy. This article challenges this stereotype, showing how it was carefully crafted in the wake of unification by the group controlling the Bank. Deconstructing this image not only re-embeds a facet of the Southern Question (namely the alleged discrimination suffered by Southern banking in the new nation state) into its historical context but also emphasises the ability of Southern financial elites to navigate the tensions between local and central authorities by developing a powerful narrative. Conspicuously absent in the historiography of the Southern Question, when these elites do surface in the occasional banking history or revisionist book, they often play the role of gallant regional champions eventually silenced by an authoritarian government, reinforcing either directly or indirectly a colonialist narrative pitting the South against the state. Yet this chivalrous picture mostly relies on sources produced by a few Southerners themselves, as the history of the Bank of Naples reveals. In pursuing very material and contingent aims, the Bank's management - appointed by local administrations - fought the government's centralising banking policy by creatively drawing on an arsenal of Risorgimento values and Bourbon myths.

This opportunistic rhetoric reflects some of the major issues debated in post-unification Italy, from the emancipation of the fatherland to the balance between central and local power and the national role of Piedmontese institutions. Unification was presented as containing the seeds of its own destruction in its putting progress and innovation before tradition and national before local identity, while the 'liberating' Italian government could turn into a power potentially more despotic than the Bourbons. Amplifying a discourse of failure and betrayal of the Risorgimento ideals that has continued to resonate ever since, the Bank justified its battles with the need to keep a tight rein on a government unable to live up to its promises. History was manipulated and stereotypes of the Southern people - proliferating after unification conveniently exploited.

To ennoble their cause, the Bank's partisans endorsed a view of post-unification Italy as teetering on the brink of internal colonialism and authoritarianism despite the financial revolution ushered in by unification and the political and economic enfranchisement achieved by the Southern elites within the new state - a bright side of the story also reflected in their takeover of the Bank of Naples. Failing to acknowledge their mastery in shaping public debate ultimately denies agency to the Southern elites, relegating them to the uncomfortable role of predestined victims. Similarly, it obscures their inner divisions - into partisans of the central or the local government, along regional lines within the South and even within the Bank itself - and the hidden weakness of the state in bargaining over local power. 


\section{Acknowledgements}

I am grateful to Mark Seymour and the anonymous referees for their valuable comments. Special thanks for their encouragement and feedback also to the Committee that has awarded me the 2019 ASMI Postgraduate Essay Prize for an earlier draft of this paper as well as to Lucy Riall, Glenda Sluga, Philip Cooke, Mate Rigo and Matilda Greig.

\section{Note on contributor}

Maria Stella Chiaruttini holds a PhD in History and Civilisation from the European University Institute (Florence) and is currently a postdoctoral researcher at the Department of Economic and Social History of the University of Vienna. She has previously worked as a research and teaching assistant at the Universities of Zurich and Göttingen, publishing several contributions on economic and financial integration. Her present research focuses on the financial history of the Risorgimento and the Southern Question.

\section{Notes}

1. On neo-Bourbonism, see Casalena 2012.

2. On Neapolitan financial elites, see also Davis 1981 and Frascani 1990.

3. On the actual extent of centralisation, see Romanelli 1988.

4. For a comprehensive overview of the history of Italian central banking, see Cardarelli et al. 1990.

5. Archivio di Stato di Napoli, Collezione delle leggi e de' decreti reali del regno delle Due Sicilie, 2, RD 12 Dec. 1816 , no. 569, 417-22.

6. Archivio Centrale dello Stato, Ministero dell'Agricoltura, Industria e Commercio, Direzione Generale del Credito e della Previdenza, Industrie, banche e società (hereafter ACS, MAIC, CP, IBS), b. 433, f. 2233 (3), Englen to the President of the General Council of the Bank of Naples, Sept. 1864 (hereafter Englen 1864a).

7. ACS, MAIC, CP, IBS, b. 432, f. 2230, Nisco to Nigra, 2 March 1861 and Nisco to Cavour, 27 March 1860 [sic, read: 1861]. Opposition to the National Bank quickly dissolved once it opened its board to some of the most influential Neapolitan bankers (Chiaruttini 2019, 215-21).

8. L'Avvenire was a Neapolitan newspaper which - though not overtly financed by the Bank - always paid close attention to its affairs, systematically taking its side.

9. The Neapolitan Il Pungolo was the double of its Milanese homonym, both close to the moderate Left and local interests (see Castronovo 1979). It was linked to the Bank through Mariano Englen, whose brother Rodolfo sat on the Bank's board.

10. La Borsa was a moderate newspaper leaning towards Catholic and municipal aspirations, while courting the Left (Capone 1970).

11. On anti-Bourbon discourse, see Moe 2002, 126-55.

12. It was also claimed that the Bank, as the state treasurer under the Bourbons, had been a powerful check on embezzlement within the public administration thanks to its sophisticated payment system. It goes without saying that the Bourbons, who had made it their treasurer to this very end, deserved no credit for this (Archivio Storico del Banco di Napoli, Atti del Consiglio Generale [hereafter ASBN, ACG] 1863, 175).

13. ACS, MAIC, CP, IBS, b. 434, f. 2236, Cacace to MAIC, 7 Jan. 1866 [sic: read 1867].

14. ASBN, ACG $1863,18$.

15. ACS, MAIC, CP, IBS, b. 435, f. 2238, 'Proposta al Consiglio Generale del Banco di Napoli' by Englen, Sept. 1864 (hereafter Englen 1864b).

16. ACS, MAIC, CP, IBS, b. 432, f. 2232, 'Sul Banco delle Due Sicilie', Oct. 1863.

17. ASBN, ACG $1863,167$.

18. ACS, MAIC, CP, IBS, b. 432, f. 2232, 'Sul Banco delle Due Sicilie', Oct. 1863.

19. ASBN, ACG 1863, 141, 164.

20. ASBN, ACG 1863, 154.

21. ASBN, ACG $1863,163,175-6$.

22. Nisco in ASBN, ACG 1863, 165-6.

23. ACS, MAIC, CP, IBS, b. 434, f. 2235, Imbriani to MAIC, 27 Sept. 1866. 
24. ASBN, ACG 1863, 245, 25; Il Popolo d'Italia 1861. Il Popolo d'Italia was a Neapolitan democratic newspaper (see Capone 1970).

25. ACS, MAIC, CP, IBS, b. 434, f. 2235, minutes of the meeting of the Board of Directors of the Bank of Naples, 17 Oct. 1866; ASBN, ACG 1867, 183-256; Cavour 2008, 611, 687.

26. ASBN, ACG 1864, 230.

27. ASBN, ACG 1864, 135.

28. Atti del Parlamento Italiano, Camera dei Deputati, Discussioni (hereafter API, CD, D), 4 May 1866, 1991, 1995-1996; 18 July 1870, 3453.

29. ACS, MAIC, CP, IBS, b. 435, f. 2238, 'Proposta al Consiglio Generale del Banco di Napoli' by Englen, 8 Feb. 1866 (hereafter Englen 1866). Cf. Englen 1864b, 7-8.

30. L'Avvenire 1866a; Englen 1866; Nisco 1866, 6, 110.

31. ACS, MAIC, CP, IBS, b. 435, f. 2238, Englen to Luzzatti, 11 July 1871 (hereafter Englen 1871); Nisco 1866, 51, 66; ASBN, ACG 1863, 143.

32. On stereotypes of Southerners, see Dickie 1999. On their usefulness in advocating for financial reforms, see Chiaruttini 2018, 14.

33. Englen 1864a. On the 'Neapolitan nation', see Pescosolido 2017, 75-91. On the conflict between local and national identities, see Banti 1996, 213-25.

34. Cf. ASBN, ACG 1867, 145-6.

35. Englen 1871; ASBN, ACG 1868, 17.

36. ASBN, ACG $1865,177$.

37. API, CD, D, 19 July 1870, 3475; 18 July 1870, 3453.

\section{References}

Aliberti, G. 1969. Classe dirigente e problemi economici nel Mezzogiorno dopo l'Unità. Salerno: Libreria internazionale editrice.

Aliberti, G., V. Corbi, G. De Antonellis, R. De Fusco, F. Fano, R. Franchini, A. Palermo et al. 1971. Storia di Napoli, vol. 10. Naples: Società editrice Storia di Napoli.

Asso, P. F., ed. 2017. Storia del Banco di Sicilia. Rome: Donzelli.

Banti, A. M. 1996. Storia della borghesia italiana. L'età liberale. Rome: Donzelli.

Barbagallo, F. 2013. La questione italiana. Il Nord e il Sud dal 1860 a oggi. Rome-Bari: Laterza.

Camera dei Deputati. 1869. Relazione della Commissione parlamentare d'inchiesta sul corso forzoso dei biglietti di banca, 3 vols. Florence: Eredi Botta.

Capecelatro, E. M. and A. Carlo. 1975. Contro la 'questione meridionale'. Studio sulle origini dello sviluppo capitalistico in Italia, 3rd ed. Rome: Savelli.

Capone, A. 1970. L'opposizione meridionale nell'età della Destra. Rome: Edizioni di storia e letteratura.

Cardarelli, S., P. Ciocca, A. Gigliobianco, P. Hertner, M. Roccas, V. Sannucci, E. Tuccimei, and A. Ulizzi. 1990. Ricerche per la storia della Banca d'Italia, vol. 1. Rome-Bari: Laterza.

Casalena, M. P. 2012. 'Controstorie del Risorgimento. Dal locale al nazionale, 2000-2011'. Memoria e Ricerca 40 (2): 163-82. DOI: 10.3280/MER2012-040010

Castronovo, V. 1979. 'Stampa e opinione pubblica nell'età liberale'. In: La stampa italiana nell'età liberale, edited by V. Castronovo, L. Giacheri Fossati and N. Tranfaglia, 1-233. Rome-Bari: Laterza.

Cavour, C. 2008. Epistolario, edited by R. Roccia, vol. 18 (2). Florence: Olschki.

Chiaruttini, M. S. 2018. 'The Lira: Token of National (Dis)Union, 1814-1874'. EUI HEC Working Papers 2018/01. Florence: European University Institute.

Chiaruttini, M. S. 2019. 'The Risorgimento and the Southern Question: A Financial History'. PhD diss., European University Institute.

Chiaruttini, M. S. 2020a. 'Banking Integration and (Under)development: A Quantitative Reassessment of the Italian Financial Divide, 1814-1874'. IBF Paper Series 03-20. Frankfurt am Main: Institut für Bankund Finanzgeschichte.

Chiaruttini, M. S. 2020b. 'Woe to the Vanquished? State, "Foreign" Banking and Financial Development in Southern Italy in the Nineteenth Century'. Financial History Review 27 (3): 340-60. DOI:10.1017/ S0968565020000220 
Corona, G. 2019. 'L'argine di "Meridiana". Oltre il divario, oltre gli stereotipi'. Meridiana 94: 9-28.

Costabile, L. and L. Neal, eds. 2018. Financial Innovation and Resilience: A Comparative Perspective on the Public Banks of Naples, 1462-1808. Cham: Palgrave Macmillan.

Daniele, V. and P. Malanima. 2011. Il divario Nord-Sud in Italia, 1861-2011. Soveria Mannelli: Rubbettino.

Davis, J. A. 1981. Merchants, Monopolists and Contractors: A Study of Economic Activity and Society in Bourbon Naples, 1815-1860. New York: Arno Press.

De Francesco, A. 2012. La palla al piede. Una storia del pregiudizio antimeridionale. Milan: Feltrinelli.

Demarco, D. 1958. Il Banco delle Due Sicilie, 1808-1863. Naples: L'Arte Tipografica.

Demarco, D. 1963. Banca e congiuntura nel Mezzogiorno d'Italia, I: 1809-1863. Naples: ESI.

Demarco, D. 1996. Opere di Domenico Demarco, vols 5-6. Naples: ESI.

De Rosa, L. 1961. Il Banco di Napoli nella vita economica nazionale, 1863-1883. Naples: L'Arte Tipografica.

Dickie, J. 1999. Darkest Italy: The Nation and Stereotypes of the Mezzogiorno, 1860-1900. New York: St. Martin's Press.

Donzelli, C. 1990. 'Mezzogiorno tra "questione" e purgatorio. Opinione comune, immagine scientifica, strategie di ricerca'. Meridiana 9: 13-53.

Felice, E. 2013. Perché il Sud è rimasto indietro. Bologna: Il Mulino.

Frascani, P. 1990. 'Mercato e commercio a Napoli dopo l'Unità'. In La Campania, edited by P. Macry and P. Villani, 185-221. Turin: Einaudi.

Il Popolo d'Italia 1861. 'Operosità governativa II'. 14 February.

Il Pungolo 1861a. 'I viglietti della Banca Nazionale'. 3 January.

Il Pungolo 1861b. 'Il Banco II'. 23 July.

Il Pungolo 1866. 'Recentissime'. 29 June.

La Borsa 1864. 'Napoli, 27 luglio'. 28 July.

L'Avvenire 1866a. 'Il Banco e la Banca'. 5 February.

L'Avvenire 1866b. 'Il Banco e la crisi monetaria'. 7 June.

L'Avvenire 1867a. 'Un rimedio sicuro IV'. 20 June.

L'Avvenire 1867b. 'Appunti finanziarii'. 17 December.

L'Avvenire 1867c. 'Appunti finanziarii III'. 18 December.

L'Avvenire 1868a. 'Ancora delle succursali del Banco di Napoli'. 26 October.

L'Avvenire 1868b. 'L'amministrazione del Banco di Napoli'. 15 December.

L'Italia 1865. 'Una maschera caduta'. 8 February.

Mataluni, G. 2018. 'Banco di Napoli, dopo cinque secoli scompare il brand'. Il Corrierino online, 22 November, accessed 16 April 2019, http://www.ilcorrierino.com/banco-di-napoli-dopo-cinquesecoli-scompare-il-brand/9032.html.

Moe, N. 2002. The View from Vesuvius: Italian Culture and the Southern Question. Berkeley: University of California Press.

Musella, L. 2010. Napoli. Dall'unità a oggi. Rome: Carocci.

Nisco, N. 1863. 'Il bilancio del Regno d'Italia. Articolo primo'. Rivista contemporanea, n. s. 32 (CX): 43-81.

Nisco, N. [1866]. Il Banco di Napoli. Lettere di Niccola Nisco deputato al Parlamento italiano. Naples: Tipografia del Giornale di Napoli.

Pescosolido, G. 2017. Nazione, sviluppo economico e questione meridionale in Italia. Soveria Mannelli: Rubbettino.

Petrusewicz, M. 1998. Come il Meridione divenne una Questione. Rappresentazioni del Sud prima e dopo il Quarantotto. Soveria Mannelli: Rubbettino.

Pezzino, P. 1992. Il paradiso abitato dai diavoli. Società, élites, istituzioni nel Mezzogiorno contemporaneo. Milan: FrancoAngeli.

Riall, L. 1998. Sicily and the Unification of Italy: Liberal Policy and Local Power, 1859-1866. Oxford: Clarendon Press.

Riall, L. 2013. Under the Volcano: Revolution in a Sicilian Town. Oxford: Oxford University Press.

Romanelli, R. 1988. Il comando impossibile. Stato e società nell'Italia liberale. Bologna: Il Mulino. 
Schisani, M. C. 2013. 'Nisco, Nicola'. In Dizionario Biografico degli Italiani, vol. 78: 590-92. Rome: Istituto della Enciclopedia Italiana.

Schisani, M. C., L. Balletta and G. Ragozini. 2021. 'Crowding Out the Change: Business Networks and Persisting Economic Elites in the South of Italy over Unification, 1840-1880'. Cliometrica 15: 89131. DOI: $10.1007 / \mathrm{s} 11698-020-00204-3$

Valsecchi, F. 1951. 'Dispotismo illuminato'. In Questioni di storia del Risorgimento e dell'unità d'Italia, edited by E. Rota, 29-73. Milan: Marzorati.

Zitara, N. 2011. L'invenzione del Mezzogiorno. Una storia finanziaria. Milan: Jaca Book.

\section{Italian summary}

Il presente articolo, attingendo alla storia del Banco di Napoli, contribuisce a far luce sulla lotta di potere fra il governo centrale e le élites meridionali nell'Italia risorgimentale. Il Banco, sin dai tempi dell'unificazione, è stato presentato come la vittima per antonomasia di un governo italiano rapace di ascendenza settentrionale. Il presente contributo, nel decostruire il mito che aleggia sul Banco, dimostra come questa caratterizzazione fu abilmente creata dalla sua stessa amministrazione napoletana. Gli amministratori del Banco, sfruttando appieno il nuovo ruolo politico ed economico da essi assunto sotto l'egida di un governo costituzionale, seppero far propri e rivestire di nuovi significati gli ideali risorgimentali al fine di promuovere tanto gli interessi del Banco quanto i propri. Spostando continuamente l'attenzione dalla finanza alla politica, essi si atteggiarono a difensori di tutte quelle libertà municipali, regionali e persino nazionali che il governo sembrava non saper, o non voler, difendere. Una simile narrazione servì da cortina fumogena per oscurare la natura economica e per certi versi privatistica dello scontro fra Banco e governo centrale e contribuì a rafforzare l'immagine, tuttora diffusa, di un Meridione vittima del nuovo stato italiano. 